\title{
EXAMINING THE EFFECTS OF STRENGTH BUILDING EXERCISES ON THE STAGE PERFOMANCE OF PROFESSIONAL FOLK DANCERS
}

\author{
Yiğit Hakan ÜNLÜ
}

Summary: Introduction: Turkish folk dances require dynamic, rhythmic and systematic movements of the body which
lead to many positive physical and physiological changes. In order to be examined the form of these changes it is
required an application of scientific approach which examines the dance as a form of physical activity with its athletic
features. Most of the Turkish folk dances require high performance of muscle strength. This is the reason why we assume
that development of the muscle strength of the dancers would result in better stage performance.
Methodology: The study is applied on 18 female and 20 male dancers, randomly divided into experimental and control
group. The groups are equal in terms of number of participants and gender. The experiment requires pre and post
testing (EG-R $O_{1} x O_{2}$ and $C G-R O_{3} O_{4}$ ). Before the application of the program all of the participants were informed
about its purpose. In order to avoid any negative effects, the pre and post assessments have been done at the same place,
at the same time of the day and following same stretching program.
Results and Discussion: The results of the study show statistically significant positive differences between the results of
pre and posttests of the experimental group which give us reason to consider it as a positive effect of the application of
the 6-week experimental program. The changes are observed not only in the means but also in the minimal, maximal
values and the range (the difference between the largest and lowest result).
Conclusion: The results of this study could be used for further application of training programs aiming development of
physical fitness and stage performance.

Keywords: exercises; dancers; dance education; strength; injuries

Introduction: During the past few decades, has been noticed a trend of professionalisation of the dance art in the Republic of Turkey and its orientation towards the scientific approach. This trend requires also a specialised training of the dancers, due to the increased artistic and aesthetic requirements demanded from them. According to Vladova and Ünlü (2017) the good dance performance depends also on the optimal development of the motor qualities and not only on the respective dancer's talent and flair. Zl. Kostov (2005) suggests that the needed set of athletic, performing and artistic qualities should be built gradually. The dances also have their proper influence on the development of the motor skills.

Nowadays, professional dance art is very close to the sport of excellence. In many aspects, the training of dancers is similar to the training of athletes, while from pedagogical point of view dance and sport activity/practice are identical (Ünlü and Vladova, 2016).

This study deals with the issue of the quality strength of Turkish folk dancers and the process of its improvement, because the optimal development of this quality is a factor for attainment of performing mastery.

Strength as a motor quality is at the foundation of good dance technique, which in its turn shall lead to the improvement of the performance. This quality is developed through systematic and purposeful training of a particular type muscular activity. In dance practice, like in sports training, are included self-weight exercises (through overcoming of the own weight) that are included mainly in the dance exercise when performing: Plie; Battement tendu; Jete; Rond de jambe par terre; Battement fondu; Battement frappe; Sauter.; external resistance exercises using weights, elastic bands, springs, etc. or structured special strength exercises (Nikolov, 2014; Vladova and Ünlü, 2017).

The development of strength by the dancers, especially in the lower body part (LBP) serves the purpose of trauma prevention and it is also necessary for the improvement of the dance performance, e.g. improvement of the balance during dancing and for the successful execution of jumps (Golomer et al., 2004; Kraemer, et al., 2004; Wyon et al., 2006; 
Ambegaonkar et al., 2014).

Turkish folk dances demand dynamic, rhythmic and systematic body movements. And it is for this reason that we consider these dances as a form of a physical activity, possessing athletic traits. The good performance of most of the Turkish folk dances (like Bar, Halay, Horon, Karşımla Zeybek, Kasik). requires a high degree of development of the muscle strength of the lower body part (limbs). For this reason, we suppose that the development of this physical quality shall lead to a better stage performance.

Methodology: The aim of this experimental study is to optimize the strength is to optimise the strength of the lower body parts of dancer who practice Turkish folk dances.

Object of the study is the development of strength of the LBP among 38 dance students from Sakarya University, Republic of Turkey. They are students at Sakarya University State Conservatory, Department of Turkish Folk Dances, Esentepe Campus Serdivan/ Sakarya, who participated in stage performances for the 2015/2016 season. Of the participants in the project 18 were female and 20 male dance students. They were divided into an experimental group $(E G=19)$ and a control group $(C G=19)$, which were balanced in terms of number of participants and gender distribution but no triage according to the year of study of the students (Table 1).

Table 1 Number of Participants

\begin{tabular}{|l|l|l|l|}
\hline & $\begin{array}{l}\text { Female } \\
\text { students }\end{array}$ & $\begin{array}{l}\text { Male } \\
\text { students }\end{array}$ & Total \\
\hline Experimental Group & 9 & 10 & 19 \\
\hline Control Group & 9 & 10 & 19 \\
\hline Total: & 18 & 20 & 38 \\
\hline
\end{tabular}

The median age of the participants from the EG is $M=22,2$ years ( $M i n=19 ; \quad M a x=28, S D=2,29)$. The average age of the participants from the Control Group is $M=21,1$ years ( $M i n=19 ; M a x=23$, $\mathrm{SD}=1,45)$. The experimental study was implemented according to a plan, comprising entry level and final testing of both groups participating students:

\section{EG - $\mathrm{R} \mathrm{O}_{1} \times \mathrm{O}_{2}$ and CG - $\mathrm{R} \mathrm{O}_{3} \mathrm{O}_{4}$}

(Legend: $R$ - randomised; $O_{1}$ - first test of the members of the EG before the start of the experiment; $x$-impact; $\mathrm{O}_{2}$ -test after the experiment; $\mathrm{O}_{3} u \mathrm{O}_{4}$ - are respectively the entry and final testing of the members of the Control group where no impact was applied) (Campbell, D, 1980).
The participants in the study were randomised to one of the two groups - experimental and control according to the criteria under study (applied strength tests on the LBP), i.e. selection in pairs. The groups were not balanced in terms of age, dance experience or anthropometric indicators, but were balanced in terms of the results from the tested indicators. The comparative analysis of the results before the experiment (Mann-Whitney test) show that there no statistically significant difference between the two groups in regard of the respective indicator could be noticed for all three tests. When selecting the groups, we have taken into account the correctness requirements to avoid the formation of quasi-experimental groups where errors usually occur (Kentawitz, Rowdiger III \& Elms, 2011). The participation in the experiment of each dance student is voluntary and the participants were informed in advance about the aims of the study. The participants were tested twice - once before the start and the second time - after the end of the experiments program. Both tests were performed in the same hall, during the same time range and after the implementation of the same warm-up exercise program. The training is performed by the same trainer in the same terms and conditions of the environment. It was mandatory, that the participants had no other physical activity on the day of the test nor on the previous day. During the testing, all participants in the survey were healthy and free of trauma.

Methodology of the Experiment: A specially elaborated work methodology has been applied to the experimental group for 6 weeks. When working with the control group this methodology was not applied. The experimental program includes: a characteristic Turkish dance exercise specially developed by the author on the base of the physical requirements demanded from the dancers who perform the basic Turkish folk dances; standard stretching complex performed after the rehearsals; specially elaborated complex for development of strength executed 3 times in the week. For enhancement of the strength of the LBP is used a combination of squats with the application of different weights which load has been progressively increased during the implementation of the project. Although the main focus of this study is the development of strength of the LBP in the combination of exercises were included abdominal and dorsal presses and push supports so that a balanced improvement of the strength qualities of the participants. The participants in the ex- 
periment continued with the regular performance of their standard dance practice.

The timing of the experiment was scheduled for the period before the first concert of the academic year.

Tests: Three tests were developed for assessment the dynamics of the development of strength of the LBP (Table 2). The data from the test results served as a criterion for the development of the strength of the LBP:

Table 2 Sports-Pedagogical Tests

\begin{tabular}{|c|c|c|c|c|}
\hline № & $\begin{array}{c}\text { Name of the } \\
\text { Test }\end{array}$ & $\begin{array}{l}\text { Focusing } \\
\text { Factors }\end{array}$ & $\begin{array}{c}\text { Measuring } \\
\text { Unit }\end{array}$ & Direction \\
\hline 1. & $\begin{array}{l}\text { Standing } \\
\text { Long Jump } \\
\text { (Test1) }\end{array}$ & $\begin{array}{c}\text { Explosive } \\
\text { force of the } \\
\text { lower limbs } \\
\text { (LBP) }\end{array}$ & $\mathrm{CM}$ & $-1+$ \\
\hline 2. & $\begin{array}{c}\text { Standing } \\
\text { Vertical } \\
\text { Jump/ Static } \\
\text { Jump } \\
\text { (Test2) }\end{array}$ & $\begin{array}{l}\text { Explosive } \\
\text { force of the } \\
\text { lower limbs } \\
\text { (LBP) - } \\
\text { muscles of } \\
\text { the foot }\end{array}$ & $\mathrm{CM}$ & $-/+$ \\
\hline 3. & $\begin{array}{l}\text { Squat Ver- } \\
\text { tical Jump } \\
\text { (Test3) }\end{array}$ & $\begin{array}{c}\text { Explosive } \\
\text { force of the } \\
\text { lower limbs } \\
\text { (LBP) }\end{array}$ & $\mathrm{CM}$ & $-/+$ \\
\hline
\end{tabular}

The testing of the explosive force of the dancers was implemented using Newtest Powertimer 300-series, which is one of the commonly used systems for testing and measuring of vertical jumps of athletes (Hennessy et al, 2001; Kyrolainen et al., 2001, 2003; Balciunas, et al., 2006). It is a reliable instrument for testing because the random errors during the measurement is insignificant (Enoksen, Tønnessen, \& Shalfaw, 2009). The data obtained with this type of measurement is easily converted into numerical values. The choice of these tests is due to the specifics of the Turkish folk dances and the need of sufficient explosive force of the LBP when performing the jumps $(70-80 \%$ of the stage dance performance require a well-developed strength of the lower limps). The tests were selected after consultations with the colleagues from the Faculty of Physical Education at the Sakarya University.

In this study alongside the testing we use expert assessment as a research method. The idea is to review the independent opinion of the experts dance pedagogues, about eventual changes of the dance performance of the participants in the pro- ject. The team of experts is made of 4 professors to the Conservatory. Each of the experts receives a Performance Assessment Card by which 6 performance indicators are evaluated: performance of dance figures and choreography; dance movements performance technique; rhythm; coordination (coordination in terms of one's own movements and coordination within the group; aesthetic attractiveness and artistry. The assessment of the performance is based on a subjective comparative analysis of video recordings, made before and after the experiment, of stage performances of dancers from both groups - the control and the experimental. The rating by the individual criteria is done on scale of 0 to 5 , where by " 0 " is marked "No positive change reported" and by " 5 " - "Significant positive change reported".

Results and discussion: After the 6-week experimental program it has been found that there is a statistically significant difference in the performance of the participants from the Experimental Group (EG) during all 3 tests (before the start and after the end of the project) (Table 3 ).

Table 3 Comparative Analysis Results (Wilcoxon Test)

\begin{tabular}{|c|c|c|c|}
\hline & Test1_2-Test1_1 & Test2_2-Test2_1 & Test3_2-Test3_1 \\
\hline $\mathbf{T}$ & -2.965 & -3.638 & -3.413 \\
\hline $\mathbf{a}$ & .003 & .000 & .001 \\
\hline
\end{tabular}

In order to verify the course of the difference we made a variation analysis of the data, presented in Table 4.

Table 4 Variation analysis of the test for assessment of the level of development of motor skills results (EG).

\begin{tabular}{|c|c|c|c|c|c|c|}
\hline 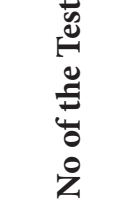 & 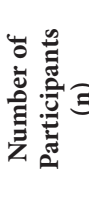 & 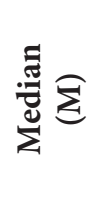 & 胥 & $\stackrel{\Xi}{\Sigma}$ & $\sum_{i}^{\stackrel{u}{*}}$ & के \\
\hline Test1_1 & 19 & 160,4 & 65 & 125,00 & 190,00 & 17,76 \\
\hline Test2_1 & 19 & 22,3 & 20 & 12,00 & 32,00 & 6,36 \\
\hline Test3_1 & 19 & 29,4 & 36 & 12,00 & 48,00 & 10,57 \\
\hline Test1_2 & 19 & 165,0 & 33 & 127,00 & 198,00 & 20,2 \\
\hline Test2_2 & 19 & 24,8 & 20 & 14,00 & 34,00 & 6,49 \\
\hline Test3_2 & 19 & 31,3 & 35 & 14,00 & 49,00 & 10,00 \\
\hline
\end{tabular}

Changes are found not only in the average but also in the minimum and maximum values and the spread (the difference between the best and the 
worst result of the trial). Based on the Wilcoxon's criterion about the dependent samples it has been found that the improvement of the indicators, subject of the research (i.e. strength of lower limbs), has a statistically credible level of significance $a \leq 0,01$.

The results of the variation and comparative analysis allow us to assume that during the 6-month experimental period an improvement of the strength of the LBP is observed and that is valid for all three tests. Alongside the positive trend dynamics of improving the indicators with respect of the median values (M) of all participants of the EG we find an increase of the indicators in respect of the minimum and maximum values as well.

In this study, the role of the Control Group (CG) is to verify the effectiveness of the development of the strength of the LBP after the implementation of the experimental program. The data from the comparative analysis of the results of the dance students from the CG during the second testing, implemented at the end of the experiment, shows that only for Test 2 (before-after) there is no statistically significant difference (Table 5).

Table 5 Comparative Analysis (Wilcoxon test) CG

\begin{tabular}{|c|c|c|c|}
\hline & $\begin{array}{c}\text { Test 1 } \\
\text { After - Before }\end{array}$ & $\begin{array}{c}\text { Test 2 } \\
\text { After - Before }\end{array}$ & $\begin{array}{c}\text { Test 3 } \\
\text { After - Before }\end{array}$ \\
\hline T & $-2,750$ & $-1,384$ & $-2,970$ \\
\hline $\mathbf{a}$ &, 006 &, 166 &, 003 \\
\hline
\end{tabular}

The results of the variation analysis show that unlike the dance students from the EG among the tested students from the CG no improvement of the studied qualities is observed and that even there is an opposite trend.

The results of the implemented expert analysis show that in regard of the expert assessment for artistry, aesthetic and rhythmic impact, both tested groups encountered similar development of the stage skills. It is worth noting that the result of improvement the overall performance of dance figures and choreography demonstrated by the members of the EG has been scored higher than that of the CG, i.e. the score of the EG is with 2 units higher than that of the CG. Un improvement of the two types of the coordination of the dancers from the EG has been found.

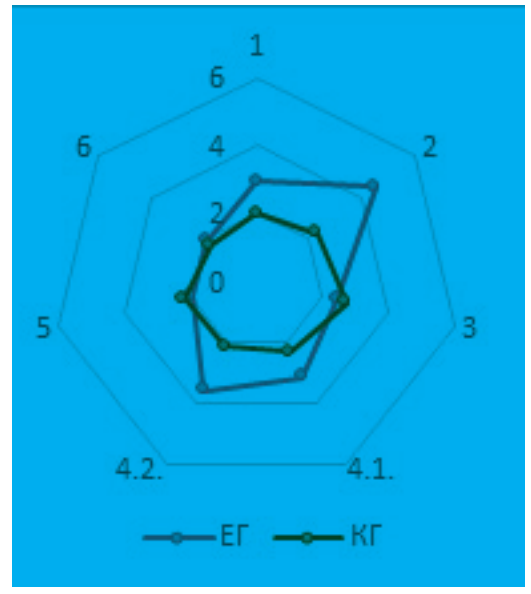

Figure 1. The Generalized results of the medial values of the assessed indicators related to the stage performance of the members of the experimental and control groups

\section{Conclusion:}

The achieved results allow to conclude that due to application of the experimental methodology there is a positive impact on the development of strength of the LBP. Considering the fact that the members of both groups participated also in the standard rehearsal program, i.e. the rehearsal conditions for all dancers were equal, we could conclude that the suggested experimental program has had a significant impact on the stage artistic performance of the dancers who took part in the project. The results of this study could be used for the further introduction of training programs aimed at the development of the physical fitness and the stage performance.

\section{References:}

Ambegaonkar, J., Caswell, S., and Cortes, N. (2014). Relationships among lower body power measures and balance in female collegiate dancers. Paper presented at the 24th Annual Meeting of the International Association for Dance Medicine \& Science. Basel, Switzerland.

Balciunas, M., Stonkus, S., Abrantes, C., and Sampaio, J. (2006). Long term effects of different training modalities on power, speed, skill and anaerobic capacity in young male basketball players. Journal of Sports Science and Medicine, 5, 163-170

Enoksen, E., Tønnessen, E., and Shalfaw, S. (2009). Validity and reliability of the Newtest Powertimer 300-series1testing system. Journal of Sports Sciences, 27(1), 77-84.

Hennessy, L. and Kilty, J. (2001). Relationship of the stretch-shortening cycle to sprint performance in trained female athletes. Journal of Strength and Conditioning Research, 15, 326-331

Golomer, E., Keller, J., Féry, Y., and Testa, M. (2004). Unipodal performance and leg muscle mass in jumping skills among ballet dancers. Percept Motor Skills. 98(2), 415-418.

Kyrolainen, H., Belli, A., and Komi, P. V. (2001). Biome- 
chanical factors affecting running economy. Journal of Medicine and Science in Sports and Exercise, 33, 13301337

Kyrolainen, H., Kivela, R., Koskinen, S., McBride, J., Andersen, J. L., Takala, T., et al. (2003). Interrelationships between muscle structure, muscle strength, and running economy. Journal of Medicine and Science in Sports and Exercise, 35, 45-49

Kraemer, W., Nindl, B., Ratamess, N., Gotshalk, L., Volek, J., Fleck, S. and Hakkinen, K. (2004). Changes in muscle hypertrophy in women with periodized resistance training. Journal of Medicine Science and Sport Exercise, 36(4), 1124-1131.

Wyon, M., Allen, N., Angioi, M., Nevill, A. and Twitchett, E. (2006). Anthropometric Factors Affecting Vertical Jump Height in Ballet Dancers. Journal of Dance Medicine \& Science, 10 (3 \& 4), 106-110.

Ünlü, Y. H., and Vladova, I. (2016). Dance lesson as a pedagogical process. E - Bildiriler Kitabı. 2 Uluslararası Müzik ve Dans Kongresi, (355-362). Muğla.

Vladova, I. and Ünlü, Y. H. (2017). On the Importance and the Need of Refinement of Flexibility and Strength as an Element of the Training of Dancers. Journal of Applied Sports Sciences, Vol. 1, pp. 31-45

Кэмпбелл, Д. (1980). Модели экспериментов в социальной психологии и прикладных исследованиях. Прогрес, Москва (Kempbel, D. Modeli eksperimentov v socialnoi psichologii I prikladnih issledovaniah. Progress, Moskva)

Костов, Зл. (2005). Теория и практика в учебнотренировъчния процес по спортни танци. Ръководство за студенти IV курс специалност „Спортни танци“ ТФ. НСА, София (Kostov. Zl. Teoria I praktika $\mathrm{v}$ uchebno-trenirovachnia process po sportni tanci. Rukovodstvo za student IV kurs, specialnost "Sportni tanci" TF, NSA, Sofia)

Николов, Е. (2014). Силата като фактор на спортното постижение. От С. Стойков (Ред.), Лека атлетика. София: НСА ПРЕС. (Nikolov, E. Silata kato factor na sportnoto postijenie. Ed. St. Stoikov. Leka atletika. Sofia, NSA PRES)

Contact information: Yiğit Hakan ÜNLÜ, PhD; Sakarya University, Turkish Folk Dance Department; tel.:+905323514147; E-mail: yhunlu@sakarya.edu.tr 